\title{
The Rhetorical Construction of the American Intervention in Libya: A Pentadic Analysis of President Barack Obama's Address to the Nation on March 28, 2011
}

\begin{abstract}
The article focuses on the rhetoric of President Barack Obama regarding the US intervention in Libya in 2011. It challenges the view that Obama was changing the course of US foreign relations and shows that his words worked to represent actions that made it impossible to shift the direction of US foreign policy. Analysis reveals that the president spoke of alternatives to military action but his language served to justify the use of force in the region. He called for action through an integrated international framework but his message was designed to diminish the US profile in public opinion and not deem the US as a controlling power. Consequently, the article suggests that mysticism provides the structural basis for Obama's perception of reality and presents options for reactions to an international crisis.
\end{abstract}

Keywords: Barack Obama, Libyan crisis, US foreign policy, crisis rhetoric, pentadic analysis

\section{Introduction}

What was involved when President Barack Obama said that he had used force in Libya and when he explained the reasons for the use of America's military power in a foreign crisis? Paraphrasing the opening question of Kenneth Burke's seminal work, A Grammar of Motives, this article asks how President Obama used language to carry out his military agenda in Libya in 2011. It seeks to present a Burkean methodology of approaching the president's words and the consequent actions during the Libyan crisis.

Previous studies have examined how presidents speak about using force in a foreign crisis and whether they make a compelling case for military action. It is a much-debated question whether crisis is a rhetorical creation or situational construction and whether presidential rhetoric constructs crisis or is constructed as a response to an event already seen as a crisis. According to Theodore Otto Windt, Jr., crisis that "does not involve an external military attack on the United States is a political event rhetorically created by the President" (8). Similarly, for Amos Kiewe, crisis occurs "when the president chooses to speak on an issue of critical dimensions, whether to promote or to minimize the perception of a crisis" (xxiii). Consequently, crisis rhetoric is "the discourse initiated by decision makers in an attempt to communicate to various constituents that a certain development is critical and to suggest a certain course of action to remedy the critical situation" (Kiewe xvii). By contrast, Jim A. Kuypers argues for "understanding crises as situationally bound and as such delimited by context (the discursive and material surroundings) acting upon text, and text upon context, within a limited period of time" (18). 
Significant discussion has also occurred over the typology of crisis rhetoric. Richard A. Cherwitz and Kenneth S. Zagacki draw a distinction between consummatory rhetoric "constituting the sole response of [the US] government to states of emergency" and justificatory rhetoric "accompanying, justifying and rationalizing specific overt military moves undertaken in response to crises" (307). Likewise, Bonnie J. Dow differentiates between epideictic rhetoric which serves to "promote continuity, restore communal feeling, and... reconcile the audience to a new situation" and deliberative rhetoric which is designed to show that policies enacted to handle them are "expedient, reasoned and prudent" (301-303). By contrast, James W. Pratt (202) and Windt (912) argue for a conception of crisis rhetoric as a homogenous type and identify its characteristic features. Robert Ivie's rhetorical investigations extend the argument to presidential war language. Studying presidential war messages, the author argues that American war rhetoric reflects continuity of "an enduring, relatively uniform vocabulary of motives for war" ("Presidential Motives for War" 340). He maintains that essential characteristics and contrasts "permeate the substance and style of the call-toarms" ("Images of Savagery in American Justifications for War" 279). Karlyn Kohrs Campbell and Kathleen Hall Jamieson's analysis supports the position, indicating that presidential war rhetoric manifests "recurring elements" (104-105). Edward J. Lordan concurs and finds in his exploration that presidential war messages "employ a number of traditional themes and rhetorical forms" (10).

A common denominator in the above scholarly conversations about the nature and classification of presidential crisis/war rhetoric is the issue of rationale for the use of force. Some writers locate presidential justification in a large frame of rhetorical action; others prioritize the role of presidential substantiation in a process leading to an armed conflict. For example, Campbell and Jamieson see the rationale for war as one of five elements shaping a specific rhetorical type (105-112), while Ivie considers the pattern of justification to be the determining factor of a rhetorical act ("Presidential Motives for War" 337-345). When addressing presidential crisis rhetoric specifically, researchers, too, analyze presidential substantiation as either a line of argumentation developed in a large context of reasoning or a strategic task dictating language choices. Windt, for instance, views presidential explanation of military decisions as one of three constituents of a rhetorical form invoked in situations declared to be critical (912), while Dan F. Hahn (15-22) and Pratt (195-202) approach presidential reasons for the use of force as the organizing principle of the presidential rhetorical performance.

This article falls within the strand of research that focuses on presidential rhetoric of justification. It argues that although President Obama said that he was changing the course of US foreign relations, his words worked to represent actions that made it impossible to shift the direction of US foreign policy. He stressed that there were alternatives to the use of force but his language served to justify the choice of military action. Consequently, the article contests the claim that Obama's position on Libya was realistic and suggests, instead, that his way of thinking and acting in the crisis reveals a mystical approach to the challenges posed by critical situations.

Research conducted on what presidents say to substantiate their use-of-force agenda and how they say it is revealing of their political approach to foreign policy making. Ivie points to presidential war vocabulary as a source of knowledge about 
presidential war motives (345). The present analysis relates to this point and claims that studying presidential crisis speeches while paying special attention to examining justifiable causes for the use of force facilitates our understanding of factors behind presidential performance in critical situations. Research along these lines gives insight into both the political self of the president and the structure and function of the rhetorical forms which expresses them. Rhetorical analyses of this nature also provide a lens to understand the American national ethos and perspective on foreign policy as it is shaped by a US sitting president and its long-term consequences.

Kenneth Burke's pentad has long been used to analyze language's function in understanding political action, and thus motivation. It has helped to explain and reveal Senator Edward Kennedy's behavior regarding the events surrounding the death of Miss Mary Jo Kopechne (Ling), Ronald Reagan's performance during the Republican primary debates (Blankenship, Fine and Davis), President Reagan's reaction to the events in Lebanon and Grenade (Birdsell), Congressman George Hansen's attempt for reelection (Kelley), Quintus Fabius Maximus's challenge of Publius Cornelius Scipio's proposal to invade Africa (Rountree), President Barack Obama's 2008 speech on race (Xiaoyan and Street), and President Donald Trump's narrative on Flickr (Chun). Applying Burke's pentad to Obama's response to the Libyan crisis, this analysis joins the scholarly conversation about presidential political performance. The findings advance the understanding of the president's decision- and action-taking regarding Libya, exposing the link between his words and actions and the motives behind them.

As defined by Burke, the pentad is a set of five terms used to describe human action and motivation: "the $a c t$ " "names what took place, in thought or deed," "the scene" provides "the background of the act" and is "the situation in which it occurred," "the agent" is "the person or kind of person" who "performed the act," "the agency" is "the means or instruments [the person] used," and "the purpose" is the reason for the act (xv). According to Burke, the pentad functions to "inquire into the purely internal relationships which the five terms bear to one another, considering their possibilities of transformation, their range of permutations and combinations - and then to see how these various resources figure in actual statements about human motives" (xvi).

This analysis follows a three-step process. First, it identifies the terms of the pentad to identify Obama's perspective on the situation in Libya. Second, it examines the relationships among the terms to suggest the dominant term and learn which aspect of the situation the president saw as the most important and to which philosophical system it corresponded. Third, it speculates what the driving force was for Obama to act in response to the situation. The speech selected for critical analysis is the Address to the Nation on the Situation in Libya delivered on 28 March 2011 at the National Defense University at Fort Lesley J. McNair in Washington, D.C.

\section{Analysis}

Act. As explained by Sonja K. Foss, the act is "the rhetor's presentation of the major action taken by the protagonist or agent" (458). Broadening the term, Pat Arneson adds that it is any conscious or purposive action (8). In the case of this analysis, the act is the US military intervention in Libya. As presented in the speech, the act is legal 
and limited. It is authorized by the United Nations Security Council, it is mandated by the international community of NATO allies, the Libyan opposition, and the Arab League, and it is proportional in duration and scope to the imminence and scale of the situation in which it takes place. The act organizes the speech. Discussion of past and planned actions guides and orders the speech's ideas. Introduced in relation to pragmatic politics, the act is reformulated to suggest concern with political idealism.

Scene. According to Foss, the scene is "the ground, location, or situation in which the rhetor says the act takes place" (459). According to Andrew King, the scene includes "the context," "the surrounding environment," "the circumstances" (169). "How the scene is designated," as Arneson explains, "indicates the scope of the analysis" and "influences the way in which the other terms in the pentad are defined" (8). In the present analysis, the scene is Libya. It is described as a regime ruled by a head of state who condones exploitation, murder, terror, assault, destruction, brutality, and repression. Descriptions of the regime's methods are reinforced with a comment of an unidentified Libyan who compares living in Libya to a 40-year nightmare. In the descriptions, the scene works to contextualize and facilitate the decision to intervene and is maintained by perpetuating the idea that military action is part of America's responsibility as a world leader. Emphasizing US leadership serves to divert the attention of public opinion away from the risks and costs of the use of force and toward the need for such action.

Agent. For King, the agent is "the person or persons who perform the actions" (170). For Foss, it involves the "main character of the situation." It is "the primary subject of the speech" (458). In the case of this speech, the agent is the United States under the presidency of Barack Obama. The distinction between the United States and Barack Obama is blurred where the issue of leadership is concerned and it is made clearer when matters of personal beliefs and attitude are discussed. From the start, the agent is referred to as simultaneously mindful of the risks and costs of intervention and of the need for action. The agent attends to the questions about action in Libya and the role of the US in policing the world wherever violence occurs. Obama positions himself as the agent who holds responsibility to act, power to authorize military action, and an obligation to account for the decision to use force. He portrays the United States as the agent driven by a sense of mission, guided by a sense of right and wrong, and convinced of its ability and indispensability to stop world violence and ensure global security. It should be noted, though, that Obama specifically mentions in the speech that he chooses to use force only when there is violence that threatens US values, when military action is demanded by the people, and when US interests are at a crossroads with those of the regime. This ternary is important in informing public opinion of the agent's motivation. The three conditions must be met for the president to use military interventions.

Agency. As King explains, the agency is "the means the agent [uses] to do the deed.... It is the method, the technique, the apparatus, or the institution we use to get the thing done" (170). In this analysis, the agency for the US intervention in Libya is force. It is portrayed as a means used only when all nonmilitary measures have been exhausted and when credibility of international institutions has been questioned. These portrayals are reinforced by assurances of the US reluctance to take military 
action. Emphasis is placed on the conduciveness of contextual factors, international consensus to act, and probability of a successful outcome. Sub-agencies also function in the speech. These include the US presidency, which gives the president the power to act and implies the support of American public opinion for the action, the UN Security Council Resolution, which provides the legal basis for the intervention, NATO-based coalition, which carries out the operation, and the Arab countries, which take direct part in the operation.

Purpose. Foss explains that the purpose is "what the rhetor suggests the agent intends to accomplish by performing the act. It is the rhetor's account of the protagonist's intentions, feelings, and values.... [I]t is the reason for action that is specified by the rhetor for the agent" (459). Arneson extends the explanation to include "the agent's private reason for performing the act. Although it may be overt, it is more often unknown to an outside observer" (8). In the case of this analysis, end of violence in Libya is given as a reason for action. A point about the US mission in Iraq is made to ensure that that the objective of US-intervention in a regime change in Libya is not considered. The goal of ending violence and crimes against civilians serves US strategic interests and justifies the president's selectivity in the use of force when arguments for military action in cases of similar crises are presented. Moreover, a higher purpose is present. It is implied that the Libyan crisis posits as a key example of the president retaining his credibility and upholding his pledge to keep the US foreign military missions limited. Moreover, it secures the position of the US as a global leader as Obama repeatedly emphasizes the success of the US capability of carrying out the operation in Libya.

Ratios. As explained by Foss, "a ratio is a pairing of two of the elements in the pentad in order to discover the relationship between them and the effect that each has on the other." Pairing terms in ratios allows to find the term that controls and defines the other terms in the pentad and thus "provides insight into what dimension of the situation the rhetor privileges or sees as most important" (460-461). In this examination, the suggested dominant term is the purpose.

Obama's description of the US mission in Libya is grounded in its purpose. From the start, the president links the act to the purpose, arguing that "when [US] interests and values are at stake, we have a responsibility to act. That's what happened in Libya over the course of these last 6 weeks." He presents his reasoning that "America has an important strategic interest in preventing Qadhafi from overrunning those who oppose him" and that "a failure to act in Libya would have carried a far greater price for America." Although Obama states that US actions in Libya tangibly helped to stop violence, avert a massacre, and prevent a humanitarian crisis, in his description, US efforts, in essence, serve US interests. The president's perspective functions rhetorically to favor national over foreign cause, domestic over foreign benefits.

In the description of the scene, there is also the implicit assumption that the act serves the purpose. According to Clarke Rountree and John Rountree, the scene controls the act and is constructed as requiring action (358). This analysis takes advantage of what the pentadic analysis offers and suggests an understanding of the terms and the relationships between them with attention focused on the purpose. From this perspective, the description of the Libyan regime drives the purpose. In Obama's 
narrative, he reports that "Innocent people were targeted for killing.... Journalists were arrested, sexually assaulted, and killed.... Military jets and helicopter gunships were unleashed upon people who had no means to defend themselves against assaults from the air." Next, the president warns that "Qadhafi declared he would show no mercy to his own people. He compared them to rats and threatened to go door to door to inflict punishment" and reminds that in the past, Qadhafi had "[hanged] civilians in the streets and [killed] over a thousand people in a single day." Finally, Obama declares that "as President, [he] refused to wait for the images of slaughter and mass graves before taking action" and responds to "those who doubted [US] capacity to carry out this operation" that "The United States of America has done what we said we would do." The president juxtaposes public opinion with the regime's tactics to generate support for his proposed counteraction. He predicts terrible consequences to rally people to the cause. The scene's description shapes public opinion's approach to and perspective on military action. It becomes a means to an end. It excuses the action, justifies the agency, and motivates with a clear purpose.

The agent described is one subdued by that purpose. The act is presented as a means of the purpose. The decision to take action involves little choice. For Obama, defending "[US] people, [US] homeland, [US] allies, and [US] core interests" means, in essence, fulfilling the duties of office of the US president. "As Commander in Chief," Obama declares, "I have no greater responsibility than keeping this country safe." "As President," he states, "my immediate concern [is] the safety of our citizens[.]" Obama's sense of duty necessitates action. The president positions himself in obligation to act. The purpose to serve the country controls him. Moreover, it mitigates his responsibility for action and, by extension, for the means taken to carry it out. Added to this are matters of America's leadership. Obama reminds that "For generations, the United States of America has played a unique role as an anchor of global security and as an advocate for human freedom," "for generations, we have done the hard work of protecting our own people, as well as millions around the globe." He adds, however, that "We have done so because we know that our own future is safer, our own future is brighter, if more of mankind can live with the bright light of freedom and dignity." If public opinion accepts this perspective, it cannot question either the reasons for US actions in Libya or means used to carry the operation out. Instead, public opinion has to conclude that the US intervention is needed and justified. Defying the action would mean defying what America stands for and benefits from. This indicates that the purpose ensures that US ideals and values prevail and that the US cause wins in public opinion.

If the higher purpose is the guiding principle behind US actions, the agency is of secondary importance. Obama declares that the US is "reluctant to use force to solve the world's many challenges" but holds that "To brush aside America's responsibility as a leader" in Libya "would have been a betrayal of who we are." He emphasizes that the US will transfer responsibility and command in Libya to NATO but fails to mention that NATO is an organization politically and militarily dominated by the US, financed and commanded largely by the US. He insists that the US mission in Libya is "limited" and "narrowly focused on saving lives" but speaks of continuing "to pursue the broader goal of a Libya that belongs not to a dictator, but to its people." There is a 
clear attempt to diminish the role of the agency in the US mission in Libya. Obama tries to shift public opinion's attention away from the risks involved in any military action towards the objectives that such action can achieve. Inconsistencies in assumptions reveal the president's will to reduce reliance on the military, on the one hand, and his strong awareness of indispensability of the US military in resolving world conflicts, on the other.

Motive. For Foss, motive explains the rhetor's action (459). For Arneson, it uncovers an often unconscious reason for performing the action (8). Discovery of motive for a particular rhetorical act helps to understand how the rhetor perceives a given situation and how he wants to react to it (Foss 461). In cases in which the purpose controls the act, mysticism serves as the system that generates suggestions for the rhetor's perception of reality and options available to him for reaction. This philosophy, as Foss explains, emphasizes "the element of unity.... Identification often becomes so strong that the individual is unified with some... universal purpose" (461). Similarly, King clarifies that texts concerned with mysticism "feature ends rather than means." They "speak of acts as small parts of a much larger system," present decisions "in terms of a larger program" (171). Mysticism, as King adds, marks a point of transition in times of confusion and compensates for doubts about direction (173). The proposed assumption that emerges from the present analysis in which the motive of the act is situated in the purpose is that Obama wants public opinion to align with the view of the world in which the US represents a unique spirit and has a special mission in the world. Positioning the obligation argument as the purpose behind his actions allows him to justify US involvement in another conflict in a Muslim country, satisfy the divisions in opinions about this engagement among the American public and within his administration, and embrace the contradictions in his own statements regarding the issue.

As Gallup polls administered on 21 March 2011 demonstrate, in the face of the conflict, majorities of young Libyans believed that they could help their country make substantial progress but they were the least likely to express the belief when compared with other young people living in Arab countries. Similarly, in the polls conducted on 22 March 2011, more Americans were found approving than disapproving of US efforts in Libya but the level of approval was the lowest when compared to support for other US military actions. Americans were divided over the role of the US in this campaign, with a plurality opposing the US taking action as a leader or sharing major responsibilities with its allies in Libya.

Beyond public opinion concerns there is the political debate between members of the Obama administration, as Secretary of State Hillary Clinton pushes for action and Secretary of Defense Robert Gates urges caution and warns of risks involved in the undertaking. Obama himself is at least ambivalent about the goal and scope of the US operation and fails to provide a clear and concrete rationale for the campaign. $\mathrm{He}$ assures that "The United States will not be able to dictate the pace and scope of this change [in Libya]. Only the people of the region can do that," but signals that "we can make a difference. I believe that this movement of change cannot be turned back and that we must stand alongside those who believe in the same core principles that have guided us through many storms." He admits that "broadening [US] military mission 
to include regime change would be a mistake," but makes statements along the lines of Qadhafi "[needs] to step down from power" which raises doubts about the limits of the task. He agrees that "America cannot use our military wherever repression occurs," but persuades "that cannot be an argument for never acting on behalf of what's right."

Playing to the obligation argument, Obama influences public opinion's interpretation of and its response to the situation in Libya. In his confrontation with an audience divided over the operation and his handling of it - the results of the Gallup polls taken on 29 March 2011 found that Americans were evenly divided in their reactions to the president's response to Libya — he adopts an attitude that means to attract majority public support and increase his approval rating. As this analysis suggests, the choice of approach appears to be rooted in the purpose, one that guides US actions and expresses its values and ideals. In seeking unity in the Libyan mission, it is speculated, however, that the president does not just want the American public to commit itself to this operation, but, more importantly, calculates to win support for future and broader US military campaigns. A variation of pentadic identification in which US interventions in foreign conflicts function as the act, foreign crisis situations as the scene, the US as the agent, US military power as the agency, and end of violence as the purpose indicate the motive of maintaining the superiority of US power and global leadership. If an act suggests the concept of an agent, and the concept of an agent suggests the concept of a scene in which the act takes place (Arneson 9), the implication is that the US will continue to intervene in foreign conflicts. From this perceptive, the US engagement in Libya serves as one operation to shape the interpretation of another military campaign and the Libyan crisis represents a small scene which takes place in a larger international conflict context.

\section{Conclusion}

If this variation is correct, then it suggests some implications concerning Obama's foreign policy making and the principles and values that inform the audience about it. First, the president's insistence on restraint in military action and development of alternative measures for managing conflict situations lacks practical value. His assurance to deal with crises through nonmilitary means goes beyond his ability to turn US foreign policy around and articulate a framework that matches the means to the challenges. Efforts to this end are largely limited by a long-standing interpretation of America's global role already constrained by who the US is and what it does. Obama may speak of pursuit of nonmilitary conflict resolution but his words do not align with his belief in the US as the world's most powerful nation with unmatched military capabilities and unshakable responsibility to act when called upon to help. Second, the president's promotion of the importance of international cooperation yields to the imperative to uphold the US supremacy. His calls to act within an integrated international approach do not seem to convey the intention to lower US global activity and importance or give up its controlling power over world developments. Instead, they appear to be part of the communication strategy designed to diminish the US profile. Obama's assertions of relegating America's participation in Libya to a secondary role are made to move US policy closer to where public opinion stands on the issue and not further away from where America resides 
on the world stage. If seen from the mystic philosophical perspective, the US always matters most and its actions always make the most difference.

\section{Works Cited}

Arneson, Pat. "The Discourse of presidents Ronald Reagan and Daniel Ortega: Peace in Nicaragua without Concession." Paper presented at the Annual Meeting of the Speech Communication Association. Boston. 1987. Print.

Birdsell, David S. "Ronald Reagan on Lebanon and Grenada: Flexibility and Interpretation in the Application of Kenneth Burke's Pentad." Quarterly Journal of Speech 73 (1987): 267-279. Print.

Blankenship, Jane, Marlene G. Fine, and Leslie K. Davis. "The 1980 Republican Primary Debates: The Transformation of Actor to Scene." Quarterly Journal of Speech 69 (1983): 25-36. Print.

Burke, Kenneth. A Grammar of Motives. Berkley and Los Angeles: University of California Press, 1969. Print.

Campbell, Karlyn Kohrs, and Kathleen Hall Jamieson. Deeds Done in Words: Presidential Rhetoric and the Genres of Governance. Chicago: University of Chicago Press, 1990. Print.

Cherwitz, Richard A., and Kenneth S. Zagacki. "Consummatory versus Justificatory Crisis Rhetoric." Western Journal of Speech Communication 50.4 (1986): 307-324. Print.

Chun, Russell Scott. "Visual Rhetoric of the Presidency: An Analysis of the Trump and Obama White House Messaging in Their First 100 days in Flickr Images." Journal of Visual Literacy 37.1 (2018): 18-39. Print.

Clarke Rountree, and John Rountree. "Burke's Pentad as a Guide for Symbol-Using Citizens." Studies in Philosophy and Education 34.4 (2015): 349-362. Print.

Dow, Bonnie J. "The Function of Epideictic and Deliberative Strategies in Presidential Crisis Rhetoric." Western Journal of Speech Communication 53.3 (1989): 294-310. Print.

Foss, Sonja K. Rhetorical Criticism. Exploration and Practice. Prospect Heights: Waveland Press, 1996. Print.

Gallup. "Americans Approve of Military Action Against Libya, 47\% to 37\%." 2011. Web. 15 Nov. 2018. https://news.gallup.com/poll/146738/AmericansApprove-Military-Action-Against-Libya.aspx.

Gallup. "Americans Resist a Major U.S. Role in Libya." 2011. Web. 15 Nov. 2018. https://news.gallup.com/poll/146840/Americans-Resist-Major-Role-Libya. aspx.

Gallup. "Before Conflict, Many Young Libyans Doubted Role in Progress." 2011. Web. 15 Nov. 2018. https://news.gallup.com/poll/146726/Conflict-YoungLibyans-Doubted-Role-Progress.aspx?g_source=link_NEWSV9\&g medium=TOPIC\&g_campaign=item_\&g_content $=$ Before $\% 2520$ Conflict $\% 2$ c\%2520Many\%2520Young\%2520Libyans\%2520Doubted\%2520Role\%252 0in\%2520Progress.

Hahn, Dan F. “Corrupt Rhetoric: President Ford and the Mayaguez Affairs.” Presidential 
Communication. Description and Analysis. Ed. Robert E. Denton, Jr., and Dan

F. Hahn. New York: Praeger, 1986. 15-24. Print.

Ivie, Robert L. "Presidential Motives for War." Quarterly Journal of Speech 60.3 (1974): 337-345. Print.

- " "Images of Savagery in American Justifications for War." Communication Monographs 47 (1980): 279-294. Print.

Kelley, Colleen E. "The 1984 Campaign Rhetoric of Representative George Hansen: A Pentadic Analysis.” Western Journal of Communication 51 (1987): 204-217. Print.

Kiewe, Amos. "Introduction." The Modern Presidency and Crisis Rhetoric. Ed. Amos Kiewe. Westport: Praeger, 1994. xv-xxxvii. Print.

King, Andrew. "Pentadic Criticism: The Wheels of Creation." Rhetorical Criticism: Perspectives in Action. Ed. Jim A. Kuypers. Lanham: Lexington Books, 2009. 165-180. Print.

Kuypers, Jim A. Presidential Crisis Rhetoric and the Press in the Post-cold War World. Westport: Praeger, 1997. Print.

Ling, David A. "A Pentadic Analysis of Senator Edward Kennedy's Address to the People of Massachusetts July 25, 1969." Rhetorical Criticism: Exploration and Practice. Ed. Sonja K. Foss. Prospect Heights: Waveland Press, 1996. 464-471. Print.

Lordan, Edward J. The Case for Combat: How Presidents Persuade Americans to Go to War. Santa Barbara: Praeger, 2010. Print.

Obama, Barack. "Address to the Nation on the Situation in Libya. March 28, 2011." The American Presidency Project. 2011. Web. 15 Nov. 2018.

https://www.presidency.ucsb.edu/documents/address-the-nation-thesituation-libya.

Pratt, James W. “An Analysis of Three Crisis Speeches.” Western Speech 34.3 (1970): 194-203. Print.

Rountree, J. Clarke, III. "The Speech of Quintus Fabius Maximus Before the Roman Senate, 205 A.D.: Status, Actus, and the Representation of Motives." Florida Communication Journal 20 (1992): 32-38. Print.

Xiaoyan, Liu, and Nancy Street. "The Analysis of Senator Barack Obama's Speech on Race by Kenneth Burke's Idea of Dramatism." International Journal of the Humanities 7.1 (2009): 83-92. Print.

Windt, Theodore Otto, Jr. "The Presidency and Speeches on International Crises: Repeating the Rhetorical Past." Speaker and Gavel 2.1 (1973): 6-14. Print. 